\title{
Epidemiology of Canine Mammary Gland Tumours in Espírito Santo, Brazil
}

\author{
Halana do Carmo Silva' , Ayisa Rodrigues de Oliveira' ${ }^{2}$ Rodrigo dos Santos Horta ${ }^{1}$, Alice Corrêa Rassele Merísio', \\ Bruna Voltolin de Sena ${ }^{3}$, Mayara Coutinho Carlos de Souza' \& Mayra Cunha Flecher'
}

\begin{abstract}
Background: Mammary tumours represent about 50 to $70 \%$ of all neoplasms in female dogs and their occurrence is directly related to the reproductive status and patient's age. The purpose of this research was to apply the Brazilian consensus on diagnosis, prognosis and treatment of canine mammary tumours and to define the regional epidemiological aspects of canine mammary gland tumours in Vitoria metropolitan region (ES, Brazil) between 2012 and 2016 and to correlate the macroscopic characteristics such as lesion size and location of the neoplasm with histopathological diagnosis, tumours grade and lymph node metastasis.

Materials, Methods \& Results: Data were collected from the archives of the Laboratory of Animal Pathology of UVV and medical records of patients attended at the Veterinary Hospital Prof. Ricardo Alexandre Hippler in 5 years (2012 to 2016). The animals were separated into groups by age to facilitate classification in the group with the highest occurrence of neoplasms. The evaluation of the macroscopic characteristics was performed through the histopathological record described in the pathology laboratory, for each patient, at the time of the initial evaluation. After descriptive analysis, data was correlated using Spearmann test, and frequency dispersion was evaluated using chi-square test, both in the software Graph Pad Prism v. 6.01. This study included 255 bitches and diagnosis of 486 lesions, once $48.6 \%$ of the dogs had more than one lesion, classified according to the Brazilian Consensus for Canine Mammary Tumours and graded according to Elston and Ellis system. 86.8\% of lesions were consistent with actual mammary neoplasms, of which $67 \%$ were malignant and $20 \%$ were benign. Non-neoplastic lesions corresponded to $7.2 \%$ of cases and 5.8\% were extra-mammary neoplasms, with an increased incidence of lipomas (39.3\%) and mast cell tumours (32.1\%). Cross-breed dogs represented 26.7\% of cases. Poodles (25.5\%), Pinschers (9.8\%) and Dachshund (4.7\%) were overrepresented. Among mammary glands, inguinal and caudal abdominal were the most affected with $30.8 \%$ and $25.4 \%$, respectively. Regarding the histopathological grade, $43.7 \%$ of the malignant mammary gland tumours were grade I, $40 \%$ grade II and $16.2 \%$ grade III. The neoplasms smaller than $3 \mathrm{~cm}$ in diameter, corresponded to $43.7 \%$ malignant neoplasms, of which 75 corresponded to grade I. Those larger or equal to $3-5 \mathrm{~cm}$ in diameter corresponded to $22.1 \%$ malignant neoplasm, of which 31 corresponded to grade II, and those larger than $5 \mathrm{~cm}$ in diameter corresponded to $25.8 \%$ malignant neoplasms, of which 34 corresponded to grade II. Macroscopic ulceration was reported in 35/486 neoplasms; of these, $85.7 \%$ were malignant. Microscopically necrosis was evidenced in $11.7 \%$ of malignant neoplasms and there was a weak, positive correlation between the occurrence of necrosis and ulceration $(P<0.0001 ; \mathrm{rs}=0.223)$, which was also correlated with tumour size and histological grade. Of these patients, $24.4 \%$ had metastases, and of these, $8.8 \%$ presented macroscopic abnormalities in the lymph node.

Discussion: Older dogs are at higher risk of developing malignant mammary gland tumour when compared to young bitches, most neoplasms with a histopathological grade III occurred in animals older than 10 years, in agreement with the literature. Age increasing might be related to more biologically aggressive mammary gland tumours. Early neutering is commonly recommended to prevent proliferative abnormalities in the mammary glands, but it has been related to several disorders, and neoplasms, in some breeds. Multiple tumours in more than one mammary gland with different histopathological diagnoses among them, isn't related to multicentric disease or worse prognosis, as also seen in this survey. Among mammary glands, the inguinal and caudal abdominal are often the most affected, as it was observed in this study; however, no differences were observed in the occurrence of malignant neoplasms, benign or non-neoplastic.
\end{abstract}

Keywords: oncology, dogs, histopathology, breast cancer.

DOI: $10.22456 / 1679-9216.89901$

Accepted: 24 February 2019

Published: 9 March 2019

${ }^{1}$ Departamento de Medicina Veterinária (DMV), Universidade Vila Velha(UVV), Vila Velha, ES, Brazil. ${ }^{2}$ Departamento de Clínica e Cirurgia Veterinária (DCCV), Escola de Veterinária (EV), Universidade Federal de Minas Gerais (UFMG), Belo Horizonte, MG, Brazil. ${ }^{3}$ Faculdade de Medicina Veterinária e Zootecnia (FMVZ), Universidade Estadual Paulista (UNESP), Jaboticabal, SP, Brazil. CORRESPONDENCE: M. Flecher [mayra.flecher@ uvv.br - Tel.: +55 (27) 3421-2185]. Universidade Vila Velha, Campus Nossa Senhora da Penha. Rua Mercúrio, s/n. Bairro Boa Vista. CEP 29102-623 Vila Velha, ES, Brazil. 


\section{INTRODUCTION}

Mammary gland tumours are very common in dogs and cats [14], representing the second most frequent tumor in dogs, and the third in cats [4]. This occurrence is directly related to the reproductive status and patient's age $[19,14]$.

Hormonal influences (mainly ovarian), obesity at a young age, fat or animal protein intake [7] were associated with an increased risk of developing breast cancer in bitches and women $[4,14,33]$. Spaying has a protective effect on the development of mammary tumours in bitches. It was found that the risk reduces to $0.5 \%$, $8 \%$ and $26 \%$ if neutering is performed before the first, second and third oestral cycles, respectively [14,24,42]. Spaying after the fourth oestrus does not reduce the risk of developing breast neoplasia in this specie [14].

Surgery is the treatment of choice for all dogs with mammary tumours, except for inflammatory carcinoma $[19,35]$ and the surgical techniques include lumpectomy or nodulectomy, simple mastectomy, regional mastectomy, or radical mastectomy [19]. The final diagnoses are only obtained after histopathological examination, usually performed after surgery.

The number of dogs presenting with mammary gland tumours is apparently high in Vitória metropolitan region, ES, Brazil, however regional epidemiological characteristics remain unknown. This study aimed to apply the Brazilian consensus [5] and define the regional epidemiological aspects of mammary gland tumours between 2012 and 2016 and to correlate the macroscopic characteristics such as lesion size and location of the neoplasm with histopathological diagnosis, tumour grade and lymph node metastasis.

\section{MATERIALS AND METHODS}

\section{Animals}

This study is a clinical and histopathological survey of bitches submitted to surgical treatment at the Veterinary Hospital Prof. Ricardo Alexandre Hippler and diagnosed by the Laboratory of Animal Pathology, at UVV, ES (Brazil) between 2012 to 2016.

Medical records were reviewed for patient's identification (breed, sex, reproductive status and age). The animals were separated into groups by age (less than 3 year-old - young, 3 to 8 - adults, and above 8 year-old - elderly) to facilitate classification in the group with the highest occurrence of neoplasms.
Histopathology

Histopathological sections stained with hematoxylin and eosin were reviewed by optic microscopy.

The classification was performed as proposed by Cassali et al. [5]. Histological grading was performed according to Elston and Ellis [9] grading system, by scoring, the amount of tubular formation, nuclear pleomorphism and number of mitoses in 10 random high-power-fields (400x).

\section{Statistical analysis}

After descriptive analysis, data was correlated using Spearmann test, and frequency dispersion was evaluated using chi-square test, both in the software Graph Pad Prism v. 6.01. Differences were considered significative if $P<0.05$. Significant correlations were considered weak when it occurred in less than $9 \%$ of the studied population ( $\mathrm{rs}<0.3$ ), moderate if it occurred in 9 to $49 \%$ of the studied cases $(0.3<\mathrm{rs}<$ 0.7 ) and strong if it occurred in more than $49 \%$ of the population ( $\mathrm{rs}>0.7$ ).

\section{RESULTS}

This study included 255 bitches and diagnosis of 486 mammary lesions (mean of 2.2 lesions per dog), once $48.6 \%$ (109/255) of the dogs had more than one lesion. Cross-breed dogs represented $26.7 \%$ of cases (68/255). Poodles (25.5\%), Pinschers (9.8\%) and Dachshund $(4.7 \%)$ were overrepresented.

Age was reported in $93.3 \%$ of the dogs $(238 / 255)$ and ranged from 2 to 16 years $(10.2 \pm 2.8)$. Most neoplasms occurred in bitches older than 8 years, representing $61.6 \%$ of cases (157/238). Dogs with 3 to 8 year-old, represented half of it ( $31 \%$ of cases, $79 / 238$ ) and those with less than 3 year-old represented only $0.8 \%(2 / 238)$ [Figure 1].

Spearmann test, revealed a weak, but positive correlation of age, with the development of malignant neoplasms $(P=0.01 ; \mathrm{rs}=0.118)$ higher histological grades $(P=0.002 ; \mathrm{rs}=0.146)$, occurrence of necrosis $(P=0.04, \mathrm{rs}=0.096)$ and lymph node metastasis $(P$ $=0.03 ; \mathrm{rs}=0.123)$. Chi-square test also revealed a greater tendency of developing malignant neoplasms in animals older than eight years $(P=0.04)$ [Table 1].

In this study, $87 \%$ of lesions (423/486) were consistent with actual mammary neoplasms, of which $67 \%$ (326/486) were malignant and 20\% (97/486) were benign. Non-neoplastic lesions corresponded to $7.2 \%$ of cases $(35 / 486)$ and $5.8 \%$ (28/486) were 
extra-mammary neoplasms (lipoma, acantholytic epidermoid carcinoma, mast cell tumour, angiolipoma, fibropapilloma, histiocytoma, collagenous hamartoma, cavernous hemangioma), with an increased incidence of lipomas (39.3\%) and mast cell tumours $(32.1 \%)$ [Figure 2].

Non-neoplastic breast lesions constituted $35 / 486$ cases $(7.2 \%)$, with a higher incidence of ductal ectasia $(37.1 \%, 13 / 35)$ and lobular hyperplasia $(11.4 \%$, 4/35). The most frequent benign neoplasms were the tubular adenoma $(45.4 \%, 44 / 97)$ and benign mixed tumor $(28.9 \%, 28 / 97)$ [Table 2].

Malignant neoplasms were composed of 292/326 (89.57\%) carcinomas, 8/326 (2.45\%) carcinossarcomas, and 26/326 (7.97\%) other histological types (special types and sarcomas). The most frequent carcinoma was the carcinoma in mixed tumour $(57.8 \%$, $188 / 326)$, followed by tubular carcinoma $(15.1 \%$, 49/326). Regarding the histological grade, $43.6 \%$ of the malignant mammary gland tumours were grade I (142/326), 39.9\% grade II (130/326) and $16.3 \%$ grade III (53/326) [Table 3].

According to the size, neoplasms smaller than $3 \mathrm{~cm}$ in diameter corresponded to 143/326 malignant neoplasms, of which 74 corresponded to grade I. Those larger or equal to $3-5 \mathrm{~cm}$ in diameter corresponded to $72 / 326$ malignant neoplasm, and of these, 31 were grade II tumours, and those larger than $5 \mathrm{~cm}$ in diameter corresponded to 84/326 malignant neoplasms, of which 34 were classified as a grade II (Table 4). According to the Spearmann's test, tumour size also correlated positively, although weakly, with malignant neoplasms $(P=0.002 ; \mathrm{rs}=0.203)$, with higher histopathological grade $(P<0.0001$, rs $=0.146)$ ulceration $(P<0.0001$; rs $=0.129)$, and metastasis in the lymph nodes $(P=$ $0.002 ; 0.175)$. Spearmann test also revealed a positive correlation of the histopathological grade with tumour size $(P<0.0001, \mathrm{rs}=0.265)$, occurrence of necrosis $(P<0.0001, \mathrm{rs}=0.233)$ and ulceration $(P<0.0001$, rs $=0.363)$. The correlations were weak for tumour size and occurrence of necrosis, but moderate for ulceration. Mammary glands inguinal and caudal abdominal were more affected, $30.8 \%$ and $25.4 \%$, respectively. Unfortunately, in this study it was possible to identify the information of the reproductive status before the diagnosis only in $47.8 \%$ (122/255) dogs. $5.9 \%$ of dogs $(15 / 255)$ were spayed before diagnoses of mammary tumor, and most of them had malignant neoplasms
$(12 / 15)$. However, it was not possible to tell at what age these bitches were neutered. Spaying was performed, along with mastectomy in $34.9 \%$ of dogs (89/255).

\section{DISCUSSION}

The genes BRCA1 and BRCA2 are known as important risk factors for the development of breast neoplasia in humans, and they were also associated with the high risk of developing mammary tumours in Cocker Spaniel $[3,27,28,42]$, although this breed was not prevalent in this study. Breed predisposition is not well established in the literature, since the difference may be related to the profile of the canine population at each survey. However, the incidence was similar to what is described by other authors $[17,25,39]$.

Most neoplasms occurred in bitches older than eight years, as described in the literature [10,24]. Mammary gland tumours occur mainly in dogs between 7 and 13 year-old, and it is considered rare in young animals, with less than 4 year-old $[14,19]$. The relative risk increased from $1 \%$ to $6 \%$ and $13 \%$ in bitches with 6,8 and 10 years, respectively [8], although large-breed dogs may develop it at a younger age [14].

Spearmann test and Chi-square test, revealed on this study, a greater tendency of developing malignant neoplasms in animals older than eight years, as evidenced by another studies [4,14,18,39]. Aging results in a greater probability of genetic mutations accumulation, and the detection and elimination of these cells by immune mechanisms occur less effectively [34]. Progression of hyperplasic or benign lesions to malignancies may take several months [14], which leads to such difference in frequency dispersion of benign or malignant mammary gland tumours in dogs, according to age.

The influence of ovarian hormones on the initiation and progression of breast neoplasms is well studied through the expression of oestrogen and progesterone receptors in mammary tissue [21]. Prolactin, oestrogen and progesterone receptors are expressed in high concentrations in the normal mammary gland, but reduced in adenomas and, especially, in carcinomas $[20,38]$. These hormones, especially when the animal receives exogenous progestogens, induce dysplastic and hyperplastic changes that can progress to benign and malignant neoplasms, with subsequent loss of hormonal dependence, from the moment the process becomes autonomous [14]. 


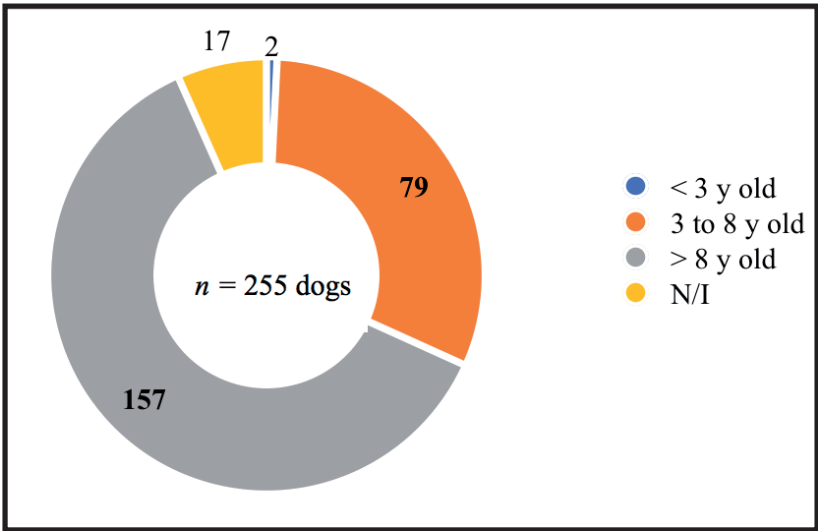

Figure 1. Mammary gland tumours by age in 255 dogs. Most neoplasms occurred in bitches older than eight years, representing 157/238 of cases, followed by cases with 3 to 8 years (79/238) and less than 3 years old (2/238). N/I: Not informed age.

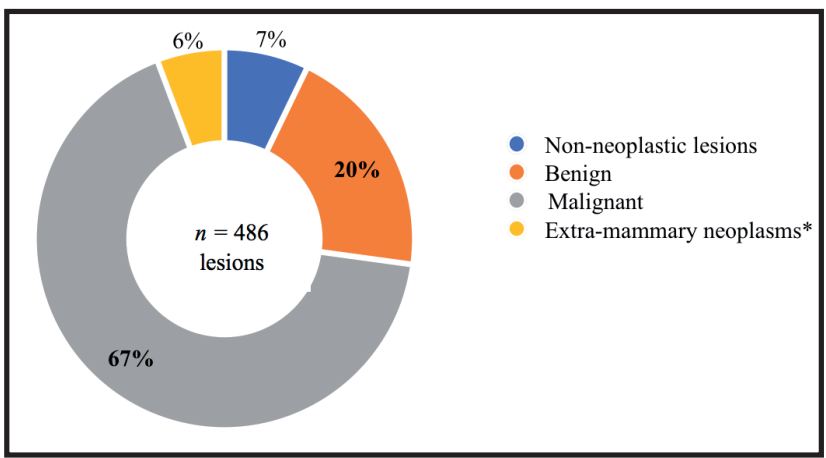

Figure 2. Distribuition of 486 mammary lesions in 255 dogs; which 422 were mammary neoplasms: 326/486 were malignant and 97/486 were benign. Non-neoplastic lesions corresponded to 35/486 of cases and 28/486 were extra-mammary neoplasms. "Lipoma, acantholytic epidermoid carcinoma, mast cell tumours, angiolipoma, fibropapilloma, histiocytoma, collagenous hamartoma, cavernous hemangioma.

Table 1. Ocurrence from 2012 to 2016 of non-neoplastic, benign and malignant mammary gland tumours in 255 female dogs, and tumour grade for malignancies according to age diagnosed at the Laboratory of Animal Pathology, Universidade Vila Velha, ES, Brazil.

\begin{tabular}{ccccccccc}
\hline $\begin{array}{c}\text { Age } \\
\text { (year-old })\end{array}$ & $\begin{array}{c}\text { Frequency } \\
(\%)\end{array}$ & $\begin{array}{c}\text { Non- } \\
\text { neoplastic } \\
(\%)\end{array}$ & $\begin{array}{c}\text { Extra } \\
\text {-mammary } \\
\text { neoplasms }\end{array}$ & $\begin{array}{c}\text { Benign } \\
(\%)\end{array}$ & $\begin{array}{c}\text { Malignants } \\
(\%)\end{array}$ & $\begin{array}{c}\text { Grade I } \\
(\%)\end{array}$ & $\begin{array}{c}\text { Grade II } \\
(\%)\end{array}$ & $\begin{array}{c}\text { Grade III } \\
(\%)\end{array}$ \\
\hline$<3$ & $2(0.4)$ & 0 & 0 & $1(1)$ & $1(0.3)$ & 0 & 0 & $1(1.9)$ \\
3 to 8 & $132(27.2)$ & $16(45.7)$ & $10(35.7)$ & $29(29.9)$ & $76(23.4)$ & $38(26.8)$ & $32(24.6)$ & $6(11.3)$ \\
$>8$ & $319(65.6)$ & $18(51.4)$ & $15(53.6)$ & $59(60.8)$ & $228(69.9)$ & $87(61.3)$ & $94(72.3)$ & $46(86.8)$ \\
N/I* & $33(6.8)$ & $1(2.6)$ & $3(10.7)$ & $8(8.2)$ & $21(6.5)$ & $14(9.9)$ & $4(3.1)$ & $3(5.7)$ \\
Total & $486(100)$ & $35(100)$ & $28(100)$ & $97(100)$ & $326(100)$ & $142(100)$ & $130(100)$ & $53(100)$ \\
\hline
\end{tabular}

* Not informed age.

The use of oestradiol ciprionate, as an abortive drug, is associated with ductal growth, although no increase in the incidence of breast tumours has been reported in dogs [19,21]. The use of synthetic progestins, such as megestrol acetate and medroxyprogesterone acetate, to prevent oestrus, is associated with lobe-alveolar development, with hyperplasia of the secretory and myoepithelial elements [22], and low doses of this hormone predisposes the formation of benign neoplastic nodules [14,21]. The combination of oestrogen and progesterone, especially when performed for long periods and in high doses, seems to induce the development of malignant breast neoplasms [14,30].

Therefore, early neutering is commonly recommended to prevent proliferative abnormalities in the mammary glands.

Nevertheless, early neutering has been related to several disorders $[1,26,29,37]$. It may impair development of external genitalia and skeletal growth, along with a greater risk of obesity, which might result in an increased risk of coxofemoral dysplasia, elbow dysplasia, and / or cranial cruciate ligament rupture, as well an increased risk of adrenal gland dysfunction, urinary incontinence, behavioural changes, hypothyroidism, epilepsy, and an onset of neoplasms, such as osteosarcoma, mainly in the Rottweiler [6]; transitional cell carcinoma of the bladder, mainly in the Scottish Terrier [26]; cutaneous mast cell tumor in Boxers, Labrador Retrievers, Golden Retrievers and Pugs [41]. Besides mast cell tumours, hemangiosarcoma and lymphoma were associated with neutering (early or late) in males and female Golden Retrievers [16,40].

Pseudocyesis is related to an early onset and higher development of malignant mammary gland tumours [25]. It is often observed in bitches due to prolonged duration of luteal phase, which leads to high concentrations of serum progesterone and consequently mammary development, followed by oestrogen and prolactin production. The intensity and duration of oestrogen and prolactin exposure in the mammary gland increases the risk of mammary cancer [33]. Prolactin facilitates the pro-mitotic action of oestrogen by increasing the expression of its receptors $[11,33]$. The 
Table 2. Non-neoplastic lesions and benign neoplasms diagnosed in 255 female dogs between 2012 at 2016 at the Laboratory of Animal Pathology, Universidade Vila Velha, ES, Brazil.

\begin{tabular}{|c|c|c|c|}
\hline Non-neoplastic epithelial lesion & Frequency $(\%)$ & Necrosis $(\%)$ & Ulceration $(\%)$ \\
\hline Adenosis & $1(2.9)$ & 0 & 0 \\
\hline Epithelial hyperplasia: & $3(8.6)$ & 0 & 0 \\
\hline Atypica & $1(2.9)$ & 0 & 0 \\
\hline Columnar & $3(8.6)$ & 0 & 0 \\
\hline Lobular & $4(11.4)$ & 0 & 0 \\
\hline Lobular with atypia & $1(2.9)$ & 0 & 0 \\
\hline Tubular & $2(5.7)$ & 0 & 0 \\
\hline Epitheliosis & $1(2.9)$ & 0 & 0 \\
\hline Duct ectasia & $13(37.1)$ & 0 & 0 \\
\hline Nipple ectasia & $2(5.7)$ & 0 & 0 \\
\hline Reactive mammary gland & $2(5.7)$ & 0 & 0 \\
\hline Sudoripal gland ectasia & $1(2.9)$ & 0 & 0 \\
\hline Tubular ectasia & $1(2.9)$ & 0 & 0 \\
\hline \multicolumn{4}{|l|}{ Benign Tumors } \\
\hline Benign mixed & $27(27.8)$ & 0 & 0 \\
\hline Complex adenoma & $14(14.4)$ & 0 & 0 \\
\hline Ductal papilloma & $5(5.2)$ & 0 & 0 \\
\hline Fibroadenoma & $7(7.2)$ & 0 & $1(33.3)$ \\
\hline Tubular adenoma & $44(45.4)$ & $2(100)$ & $2(66.7)$ \\
\hline
\end{tabular}

pseudocyesis was informed in 24 clinical files (24/255), of which $18(7.06 \%)$ presented this pathology, and due to insufficient data, it was not possible to correlate it with the incidence of mammary gland tumours.

Among mammary glands, the inguinal and caudal abdominal (M5 and M4) are often the most affected [10,14,23,39], as it was observed in this study, representing $30.8 \%$ and $25.4 \%$ of mammary gland tumours, respectively. The explanation for the greater frequency of this location is that these glands present a greater amount of mammary parenchyma, and, therefore, an increased number of hormonal receptors $[14,36]$. However, no differences were observed in the occurrence of malignant neoplasms, benign or non-neoplastic, by the chi-square test $(P=0.4)$ and there was no correlation with the other studied variables.

In this study, $48.6 \%(109 / 255)$ of the dogs had more than one lesion, and $85 \%$ of dogs $(217 / 255)$ had at least one malignant mammary gland tumour. These results are similar to those described by other surveys $[2,12,17]$, in which $60 \%$ of the dogs presented multiple tumours in more than one mammary gland with different histopathological diagnoses among them, although these is not be related to multicentric disease or worse prognosis [35]. Cassali [4] states that about $50 \%$ of breast neoplasms are benign and that carcinomas correspond to approximately $45 \%$. Nevertheless, in this study, the distribution of lesions was similar to what is reported by other Brazilian studies, with an incidence of malignancies exceeding $60 \%$, probably due to the delay in the search for veterinary assistance $[10,11,17,24]$, and transformation of benign mixed tumor into in situ or invasive lesions [5]. First world countries reveal a different picture with an incidence of malignancy between 41 to $53 \%$ [11,19,31].

The most frequent benign neoplasms were the tubular adenoma $(45.4 \%, 44 / 97)$ and benign mixed tumour $(28.9 \%, 28 / 97)$ [Table 2], which differs from Horta et al. [17], in Belo Horizonte (MG, Brazil), that showed a higher frequency of benign mixed tumour.

Among the malignant neoplasms the most frequent was the carcinoma in mixed tumour according to the Brazilian classification [5], which corroborates the fin- 
Table 3. Malignant mammary neoplasms diagnosed in 255 female dogs between 2012 and 2016 at the Laboratory of Animal Pathology, Universidade Vila Velha, ES, Brazil. Correlation with malignancy x grade x lymph node metastases x necrosis x ulceration.

\begin{tabular}{|c|c|c|c|c|c|c|c|}
\hline CARCINOMA & $\begin{array}{l}\text { Frequency } \\
\qquad \%)\end{array}$ & $\begin{array}{l}\text { Grade I } \\
(\%)\end{array}$ & $\begin{array}{l}\text { Grade II } \\
(\%)\end{array}$ & $\begin{array}{l}\text { Grade III } \\
\quad(\%)\end{array}$ & $\begin{array}{l}\text { Lymph node } \\
\text { metastasis (\%) }\end{array}$ & $\begin{array}{c}\text { Necrosis } \\
(\%)\end{array}$ & $\begin{array}{l}\text { Ulceration } \\
(\%)\end{array}$ \\
\hline In mixed tumour & $188(57.8)$ & $87(61.3)$ & $82(63.1)$ & $19(35.8)$ & $40(44.4)$ & 17 (44.7) & $10(33.3)$ \\
\hline Ductal in situ & $6(1.8)$ & $4(2.8)$ & $2(1,5)$ & 0 & $1(1.1)$ & 0 & 0 \\
\hline comedo & $2(0.6)$ & $1(0.7)$ & 0 & $1(1,9)$ & $1(1.1)$ & $1(2.6)$ & 0 \\
\hline cribiform pattern & $1(0.3)$ & 0 & 0 & $1(1,9)$ & $1(1.1)$ & 0 & $1(3.3)$ \\
\hline micropapillary & $1(0.3)$ & 0 & $1(0.8)$ & 0 & $1(1.1)$ & 0 & 0 \\
\hline papillary & $11(3.4)$ & $5(3.5)$ & $6(4.6)$ & 0 & $2(2.2)$ & $1(2.6)$ & $3(10)$ \\
\hline solid & $1(0.3)$ & $1(0.7)$ & 0 & 0 & 0 & 0 & 0 \\
\hline Papillary & $11(3.4)$ & $5(3.5)$ & $6(4.6)$ & 0 & $2(2.2)$ & 0 & 0 \\
\hline invasive & $2(0.6)$ & $1(0.7)$ & $1(0.8)$ & 0 & $1(1.1)$ & 0 & 0 \\
\hline non-invasive & $1(0.3)$ & $1(0.7)$ & 0 & 0 & 0 & 0 & 0 \\
\hline Solid & $19(5.8)$ & $4(2.8)$ & $6(4.61)$ & $9(17)$ & $6(6.6)$ & $8(21.1)$ & $4(13.3)$ \\
\hline Tubular & $49(15.1)$ & $28(19.7)$ & $18(13.8)$ & $3(5,7)$ & $19(21.1)$ & $2(5.3)$ & $4(13.3)$ \\
\hline \multicolumn{8}{|l|}{ Special Type } \\
\hline Anaplastic & $5(1.5)$ & 0 & $3(2.3)$ & $2(3.8)$ & $3(3.4)$ & 0 & 0 \\
\hline Basal cell & $1(0.3)$ & $1(0.7)$ & 0 & 0 & $1(1.1)$ & 0 & $1(3.3)$ \\
\hline Invasive lobular & $1(0.3)$ & 0 & 0 & $1(1.9)$ & $1(1.1)$ & 0 & $1(3.3)$ \\
\hline Lipid-rich & $1(0.3)$ & $1(0.7)$ & 0 & 0 & 0 & $1(2.6)$ & 0 \\
\hline $\begin{array}{c}\text { Malignant } \\
\text { adenomyoepithelioma }\end{array}$ & $2(0.6)$ & 0 & 0 & $2(3.8)$ & $1(1.1)$ & $2(5.3)$ & $1(3.3)$ \\
\hline Mammary & $1(0.3)$ & $1(0.7)$ & 0 & 0 & 0 & 0 & 0 \\
\hline Micropapillary & $3(0.9)$ & 0 & 0 & $3(5.7)$ & $3(3.3)$ & 0 & $1(3.3)$ \\
\hline Spindle-cell & $3(0.9)$ & $1(0.7)$ & $1(0.8)$ & $1(1.9)$ & $1(1.1)$ & $1(2.6)$ & $1(3.3)$ \\
\hline Squamous cell & $4(1.2)$ & 0 & $1(0.8)$ & $3(5.7)$ & $2(2.2)$ & $2(5.3)$ & $1(3.3)$ \\
\hline Carcinosarcomas & $8(2.5)$ & - & - & - & $4(4.4)$ & $1(2.6)$ & 0 \\
\hline \multicolumn{8}{|l|}{ Sarcomas } \\
\hline Osteosarcoma & $2(0.6)$ & - & - & - & 0 & $2(5.3)$ & $1(2.6)$ \\
\hline Undifferentiated & $2(0.6)$ & - & - & - & 0 & 0 & $1(2.6)$ \\
\hline Hemangiosarcoma & $1(0.3)$ & - & - & - & 0 & 0 & 0 \\
\hline
\end{tabular}

Table 4. Frequency of mammary gland tumors, malignancy and histopathological grade, according to tumour size diagnosed in the period of 2012 to 2016 at the Laboratory of Animal Pathology, Universidade Vila Velha, ES, Brazil.

\begin{tabular}{cccccc}
\hline Size & Frequency $(\%)$ & Malignancy $(\%)$ & Grade I $(\%)$ & Grade II (\%) & Grade III (\%) \\
\hline $\mathrm{T} 1(<3 \mathrm{~cm})$ & $238(49)$ & $143(43.8)$ & $74(53.2)$ & $53(40.8)$ & $15(25.4)$ \\
$\mathrm{T} 2(3-5 \mathrm{~cm})$ & $95(19.5)$ & $72(22.1)$ & $27(19.4)$ & $31(23.8)$ & $16(27.1)$ \\
$\mathrm{T} 3(>5 \mathrm{~cm})$ & $106(21.8)$ & $84(25.7)$ & $25(18)$ & $34(26.2)$ & $25(42.4)$ \\
N/I* & $47(9.7)$ & $27(8.2)$ & $13(9.4)$ & $12(9.2)$ & $3(5.1)$ \\
Total & $486(100)$ & $326(100)$ & $139(100)$ & $130(100)$ & $59(100)$ \\
\hline
\end{tabular}

"Not informed size. 
dings of earlier studies [10,23], corresponding to $188 / 326$ (57.7\%). Followed by tubular carcinomas, corresponding to $15 \%$, (49/326). These results converge with another study $[14,15]$ that found a similar prevalence of tubular carcinomas (17/63), when using the Brazilian consensus.

The prevalence according to tumour grade different from Frehse et al. [13], who reported a higher occurrence of grade II tumours. Most neoplasms with a histopathological grade III occurred in animals older than 10 years $(P<0.0001)$, and in agreement with the literature, age increasing might be related to more biologically aggressive mammary gland tumours $[14,18]$.

Chi-square test revealed a higher tendency to malignancy and a higher histological grade in T2 (3-5 $\mathrm{cm})$ and $\mathrm{T} 3(>5 \mathrm{~cm})$ lesions compared to T1 $(<3 \mathrm{~cm})$ lesions, with $P=0.0002$ and $P=0.05$, respectively, as stated by Feliciano et al. [11] and Goldschmidt et al. [14]. T2 and T3 lesions also had a higher grade compared to T1 lesions, with $P=0.001$. The worst prognosis occurs in tumours with $3-5 \mathrm{~cm}$ in diameter [14], however, in the present study, the disease-free interval, overall survival and prognosis of these patients were not evaluated.

Macroscopic ulceration was reported in 35/486 mammary lesions. Of these, $85.7 \%$ (30/35) were malignant. This result was superior to that observed by Oliveira et al. [25] who observed that $72.7 \%$ of the ulcerated tumours corresponded to malignant mammary gland tumours, confirming the ulceration as indicative of malignancy. Necrosis was evidenced, microscopically in $11.7 \%$ of malignant neoplasms (38/326) and there was a weak, positive correlation between the occurrence of necrosis and ulceration $(P<0.0001$; rs $=0.223)$, which also correlated with tumour size and histological grade, as previously described. Necrosis also showed a weak, positive correlation with the occurrence of lymph node metastasis $(P=0.03$; rs $=$ $0.123)$, which did not occur for ulceration. However, Santos et al. [32] showed no influence of necrosis and ulceration on survival and disease-free interval in bitches with malignant mammary tumours.

The lymphatic system represents the main pathway for metastasis of malignant mammary tumours
[5,35], however, only 106 lymph nodes of 217 diagnoses with at least one malignant mammary tumour were removed and identified with histopathological examination, due to the surgical technique chosen and the difficulty of resection of the axillary lymph nodes in the surgeries that involved the resection of the cranial glands. Of these patients, $53(24.4 \%)$ had metastases, and 23, 30 and 20 presented grade I, II and III tumours, respectively. In 19 patients $(8.8 \%)$, the lymph node was macroscopic enlarged, and in $34(15.7 \%)$ there was no metastasis.

The limitations of this study were the imprecision of information about reproductive status (pseudocyesis, contraceptive use, and age at which ovariohysterectomy was performed), impossibility to determine body score, heterogeneity of clinical-surgical treatments, and lack of clinical follow-up. However, this study allowed the identification of the most frequent histological types, according to the Brazilian classification [5], in addition to the characterization of prognostic factors already established in the literature (tumour size, lymph node involvement, histological grade), thus increasing the knowledge about the distribution of mammary gland tumours in dogs, especially in the Vitória metropolitan region, ES, Brazil.

In this study was possible to identify the information of the reproductive status before the diagnosis only in $47,8 \%(122 / 255)$ dogs. Fifteen dogs $(5,9 \%)$ were spayed before diagnosis of mammary tumors, and most of them had malignant neoplasms (12/15). However, it was not possible to tell at what age these bitches were neutered. Spaying was performed, along eith mastectomy in $34,9 \%$ of dogs $(89 / 255)$.

\section{CONCLUSION}

The results of this survey agree with a lot of others in the literature, and it represents the first epidemiological study of canine mammary tumours in Espírito Santo, Brazil. Tumor size, lymph node involvement, histopathological type, tumour grade, ulceration and necrosis are crucial information, for clinical and pathological approaches to canine mammary neoplasms.

\section{REFERENCES}

1 Arnold S., Hubler M. \& Reichler I. 2009. Urinary incontinence in spayed bitches: new insights into the pathophysiology and options for medical treatment. Reproduction in Domestic Animals. 44 (2): 190-192.

2 Benjamin S.A., Lee A.C. \& Saunders W.J. 1999. Classification and Behavior of Canine Epithelial Neoplasms Based on Life-Span Observations in Beagles. Veterinary Pathology. 36: 423-436. 
3 Borge K.S., Børresen-Dale A.L. \& Lingass F. 2011. Identification of genetic variation in 11 candidate genes of canine mammary tumour. Veterinary and Comparative Oncology. 9(4): 241-250.

4 Cassali G.D. 2015. Patologia da Glândula Mamária. In: Nascimento E.F. \& Santos R.L. (Eds). Patologia da Reprodução dos Animais Domésticos. 3.ed. Rio de Janeiro: Guanabara Koogan, pp.133-115.

5 Cassali G.D., Lavelle G.E., De Nardi A.B., Ferreira E., Bertagnolli A.C., Estrela-Lima A., De Nardi A.B., Ghever C., Sobral R.A., Amorim R.L., Oliveira L.O., Sueiro F.A.R., Beserra H.E.O., Bertagnolli A.C., Gamba C.O., Damasceno K.A., Campos C.B., Araujo M.R., Campos L.C., Monteiro L.N., Nunes F.C., Horta R.S., Reis D.C., Luvizotto M.C.R., Magalhães G.M., Raposo J.B., Ferreira A.M.R., Tanaka N.M., Grandi F., Ubukata R., Batschinski K., Terra E.M., Salvador R.C.L., Jark P.C., Delecrodi J.E.R., Nascimento N.A., Silva D.N., Silva L.P., Ferreira K.C.R.S., Frehse M.S., Santis G.W., Silva E.O., Guim T.N., Kerr B., Cintra P.P., Silva F.B.F., Leite J.S., Mello M.F.V., Ferreira M.L.G., Fukumasu H., Salgado B.S. \& Torres R. 2014. Consensus for the diagnosis, prognosis and treatment of canine mammary tumours. Brazilian Journal Veterinary Pathology. 7(2): 38-69.

6 Cooley D.M., Beranek B.C., Schlittler D.L., Glickman M.W., Glickman L.T. \& Waters D.J. 2002. Endogenous gonadal hormone exposure and bone sarcoma risk. Cancer Epidemiology Biomarkers \& Prevention. 11: 1434-1440.

7 De Nardi A.B., Rodaski S., Souza R.S., Costa T.A., Macedo T.R., Rodigheri S.M., Rios A. \& Piekarz C.H. 2002. Prevalência de neoplasias e modalidades de tratamentos em cães, atendidos no Hospital Veterinário da Universidade Federal do Paraná. Archives of Veterinary Science. 7(2): 15-26.

8 Egenvall A., Bonnet B.N. \& Ohagen P. 2005. Incidence and survival after mammary tumours in a population of over 80,000 insured female dogs in Sweden from 1995 to 2002. Preventive Veterinary Medicine. 69: 109-127.

9 Elston C.W. \& Ellis I.O. 1991. Pathological prognostic factors in breast cancer, I: the value of histological grade in breast cancer: experience from a large study with long-term follow-up. Histopathology. 19(5): 403-410.

10 Estrela-Lima A., Neto J.M.C., Oriá A.P., Moreira E.L.T., Peixoto TC, Muramoto C., D'assis M.J.M.H., Vieira Filho C.H.C., Machado M.C.A., Nascimento N.A., Silva D.N., Martins Filho E.F., Gomes E.A., Silva L.P., Requião L.G.T. \& Fontes T.N. 2014. Clinical Pathological Study of Mammary Tumours in Female Dogs from the Veterinary Hospital of UFBA - Bahia, Brazil. Brazilian Journal Veterinary Pathology. 7(2): 106-143.

11 Feliciano M.A.R., Silva A.S., Peixoto R.Y.R., Galera P.D. \& Vicente W.R.R. 2012. Estudo clínico, histopatológico e imunoistoquímico de neoplasias mamárias em cadelas. Arquivo Brasileiro de Medicina Veterinária e Zootecnia. 64(5): 1094-1100.

12 Fowler E.H., Wilson G.P. \& Koester A. 1974. Biologic Behavior of Canine Mammary Neoplasms Based on a Histogenic Classification. Veterinary Pathology. 11: 212-229.

13 Frehse M.S., Bracarense A.P.F.R.L., Santis G.W., Silva E.O., Freire R.L., Machado M.A. \& Martins M.I.M. 2014. Epidemiological and Histological Aspects of Canine Mammary Tumours Diagnosed at the Veterinary Teaching Hospital/UEL. Brazilian Journal Veterinary Pathology. 7(2): 106-143.

14 Goldschmidt M., Penã L. \& Zappulli V. 2017. Tumours of the Mammary Gland. In: Meuten D.J. (Ed). Tumours in Domestic Animals. 5th edn. Ames: Wiley-Blackwell, pp.723-765.

15 Gundim L.F., Araújo C.P., Blanca W.T., Guimarães E.C. \& Medeiros A.C.A. 2016. Clinical staging in bitches with mammary tumours: Influence of type and histological grade. Canadian Journal of Veterinary Research. 80: 318-322.

16 Hart B.L., Hart L.A., Thigpen A.P. \& Willits N.H. 2014. Long-term health effects of neutering dogs: Comparison of labrador retrievers with golden retrievers. PLOS ONE. 9(7). e102241. doi: 10.1371/journal.pone.0102241.

17 Horta R.S., Lavalle G.E., Cunha R.M.C., Moural L.L., Araújo R.B. \& Cassali G.D.C. 2014. Influence of Surgical Technique on Overall Survival, Disease Free Interval and New Lesion Development Interval in Dogs with Mammary Tumours. Advances in Breast Cancer Research. 3: 38-46.

18 Kim H.W., Lim H.Y., Shin J.I., Seung B.J., Ju J.H. \& Sur J.H. 2016. Breed- and age-related differences in canine mammary tumours. Canadian Journal of Veterinary Research. 80: 146-155.

19 Lana S.E., Rutteman G.R. \& Withrow S.J. 2007. Tumours of the mammary gland. In: Withrow S.J. \& MacEwen E.G. (Eds). Small Animal Clinical Oncology. 4th edn. Philadelphia: W.B. Saunders Co., pp.619-636.

20 Michel E., Feldmann S.K., Kowalewski M.P., Bley C.R., Boos A., Guscetti F. \& Reichler I.M. 2012. Expression of prolactin receptors in normal canine mammary tissue, canine mammary adenomas and mammary adenocarcinomas. Veterinary Research. DOI: 10.1186/1746-6148-8-72. 
21 Millán Y., Guil-Luna S., Reymundo C., Sánchez-Céspedes R. \& Las Mulas J.M. 2013. Sex Steroid Hormones and Tumours in Domestic Animals. In: Payan-Carreira R. (Ed). Insights from Veterinary Medicine. Vila Real: IntechOpen, pp.191 -214.

22 Misdorp W. 1991. Progestagens and mammary tumours in dogs and cats. Acta Endocrinologica. 125: 27-31.

23 Nunes F.C., Gamba C.O., Damasceno K.A., Campos C.B., Horta R.S., Araújo M.R., Monteiro L.N., Lavalle G.E., Ferreira E. \& Cassali G.D. 2014. Analisis of Clinico Pathological Data Therapeutical Conduct and Overall Survival of Canine Mammary Lesions Attended at the Veterinary Hospital of the Federal University of Minas Gerais (UFMG). Brazilian Journal Veterinarian Pathology. 7(2): 106-143.

24 Oliveira Filho J.C., Kommers G.D., Masuda E.K., Marques B.M.F.P.P., Fighera R.A., Irigoyen L.F. \& Barros C.S.L. 2010. Estudo retrospectivode 1.647 tumores mamários em cães. Pesquisa Veterinária Brasileira. 30: 177-185.

25 Oliveira L.O., Oliveira R.T., Loretti A.P., Rodrigues R. \& Driemeier D. 2003. Aspectos epidemiológicos da neoplasia mamária canina. Acta Scientiae Veterinariae. 31(2): 105-110.

26 Reichler I. 2009. Gonadectomy in cats and dogs: a review of risks and benefits. Reprodution in Domestic Animals. 44(s2): 29-35.

27 Rivera P. 2010. Biochemical Markers and Genetic Risk Factors in Canine Tumours. 82f. Uppsala, SWE. Dissertação (Doctoral thesis) Department of Clinical Sciences, Swedish University of Agricultural Sciences.

28 Rivera P., Melin M., Biagi T., Fall T., Häggström J., Lindblad-Toh K. \& Von Euler H. 2009. Mammary tumor development in dogs is associated with BRCA1 and BRCA2. Cancer Research. 69: 8770-8774.

29 Romagnoli S. 2017. Early-age neutering in dogs and cats: advantages and disadvantages. Revista Brasileira de Reprodução Animal. 41(1): 130-132.

30 Rutteman G.R. 1992. Contraceptive steroids and the mammary gland: is there a hazard? Breast Cancer Research and Treatement. 23: 29-41.

31 Salas Y., Márquez A., Diaz D.l. \& Romero L. 2015. Epidemiological Study of Mammary Tumours in Female Dogs Diagnosed during the Period 2002-2012: A Growing Animal Health Problem. PLoS One. 18;10(5): e0127381.

33 Santos A.A., Lopes C.C., Ribeiro J.R., Martins L.R., Santos J.C., Amorim I.F., Gärtner F. \& Matos A.J. 2013. Identification of prognostic factors in canine mammary malignant tumours: a multivariable survival study. BMC Veterinary Research. 9(1): 1-11.

34 Silva A.E., Serakides R. \& Cassali G.D. 2004. Carcinogênese hormonal e neoplasias hormônio-dependentes. Ciência Rural. 34(2): 625-633.

35 Sleeckx N., Rooster H., Veldhuis Kroeze E.J.B., Van Ginneken C. \& Van Brantegem L. 2011. Canine Mammary Tumours, an Overview. Reprodution in Domestic Animals. 46: 1112-1131.

36 Sorenmo K.U. 2003. Canine mammary gland tumours. Veterinary Clinics of North America: Small Animal Practice. 33: 573-596.

37 Sorenmo K.U., Rasotto R.,Zappulli V. \& Goldschmidt M.H.2011. Development, anatomy, histology, lymphatic drainage, clinical features, and cell differentiation markers of canine mammary gland neoplasms. Veterinary Pathology. 48(1): 85-97.

38 Spain V.C., Scarlett J.M. \& Houpt K.A. 2004. Long-term risks and benefits of early-age gonadectomy in dogs. Journal of the American Veterinary Medical Association. 224(3): 380-387.

39 Spoerri M., Guscetti F., Hartnack S., Boos A., Oei C., Balogh O., Nowaczyk R.M., Michel E., Reichle I.M. \& Kowalewski M.P. 2015. Endocrine control of canine mammary neoplasms: serum reproductive hormone levels and tissue expression of steroid hormone, prolactin and growth hormone receptors. BMC Veterinary Research. 11:235.

40 Toríbio J.M.M.L., Lima A.E., Martins Filho E.F., Ribeiro L.G.R., D'assis M.J.H., Teixeira R.G., Damasceno K.A., Cassali G.D. \& Costa Neto J.M. 2012. Caracterização clínica, diagnóstico histopatológico e distribuição geográfica das neoplasias mamárias em cadelas de Salvador, Bahia. Revista Ceres. 59(4): 427-433.

41 Torres De La Riva G., Hart B.L., Farver T.B., 2013. Oberbauer A.M., Messam L.L.M., Willits N. \& Hart L.A. 2013. Neutering Dogs: Effects on Joint Disorders and Cancers in Golden Retrievers. PLoS One. 8(2): e55937.

42 White C.R., Hohenhaus A.E., Kelsey J. \& Procter-Grey E. 2011. Cutaneous MCTs: Associations with spay/neuter status, breed, body size, and phylogenetic cluster. Journal of the American Animal Hospital Association. 47: 210-216.

43 Zatloukal J., Lorenzová J., Tichý F., Necas A., Kecová H. \& Kohout P. 2005. Breed and age as Risk Factors for Canine Mammary Tumours. Acta Veterinaria Brunensis. 74: 103-109. 